\title{
$\mathrm{Mg}-\mathrm{Zn}-\mathrm{Y}(\mathrm{ZW} 61)$ 합금에서 Icosahedral 준결정상의 석출
}

곽호연 - 이갑호 ${ }^{\dagger}$

충남대학교 나노소재공학과

\section{Precipitation of Icosahedral Qusicrystal Phase in Mg-Zn-Y(ZW61) alloy}

\author{
Ho Yeon Kwak and Kap Ho Lee ${ }^{\dagger}$
}

Department of Nano Materials Engineering, Chungnam National university, Daejeng 305-764, Korea

(2011년 1월 18일 접수 : 2011년 2월 12일 최종수정 : 2011년 2월 13일 채택)

\begin{abstract}
Precipitation of the ordered icosahedral quasicrystal in Mg- $6 \mathrm{wt} \% \mathrm{Zn}-1 \mathrm{wt} \% \mathrm{Y}$ alloy has been characterized by transmission electron microscopy observations. The lamellar-type icosahedral qusicrystal phases (I-phase) with the face-centered icosahedral (FCI) structure are observed in alloy after solution treatment at $550^{\circ} \mathrm{C}$. In the alloy annealed at $400^{\circ} \mathrm{C}$, polygonshaped I-phases are observed in the $\alpha-\mathrm{Mg}$ matrix. The interfaces of the I-phase with the matrix are facetted and the facets are on five-fold and two- fold plane of the I-phase. The orientation relationship of the I-phase with the matrix is determined to be $[15]_{\mathrm{I}} / /[001]_{\mathrm{Mg}},(2 \mathrm{f})_{\mathrm{I}} / /(2 \overline{1} 0)_{\mathrm{Mg}}$ and $[12]_{\mathrm{I}} / /[311]_{\mathrm{Mg}},(5 \mathrm{f})_{\mathrm{I}} / /(0 \overline{1} 1)_{\mathrm{Mg}}$. The icosahedral grains are occasionally found to be twinned with one of the five-fold axis as the twin axis. The twin boundaries appear to be fairly straight and perpendicular to the fivefold twin axis. The icosahedral twin can be expressed as a rotation of $63.4^{\circ}$ or $116.6^{\circ}$ around two fold zone axis.
\end{abstract}

Key words Mg-Zn-Y alloy, icosahedral quasicrystal phase, orientation relationship, twin structure, high resolution transmission electron microscopy.

\section{1. 서 론}

$\mathrm{Mg}-\mathrm{Al}$ 및 $\mathrm{Mg}-\mathrm{Zn}$ 계에 기초를 둔 대부분의 마그네슘합 금은 시효경화형 합금으로, 가장 기대되는 강화기구는 시 효처리에 의해 석출상들을 기지내에 미세하게 분산시키 는 방법이다. 분산된 석출상들의 종류, 크기 및 분포는 합금조성 및 시효온도에 따라서 달라지며, 기지와 석출 상들 사이의 방위관계는 합금의 기계적 특성을 결정하는 중요한 인자중의 하나이다. ${ }^{1-2)}$

$\mathrm{Mg}-\mathrm{Zn}$ 및 $\mathrm{Mg}-\mathrm{Zn}-\mathrm{RE}$ (RE: 희토류 원소) 합금계에서 알려진 석출 강화상으로는 $\beta_{1}{ }^{\prime}, \beta_{2}{ }^{\prime}, 20$ 면체의 준결정상 (icosahedral quasicrystal phase; 이후 I-상이라 함) 등이 있다.-6) 준결정상은 일반적인 금속상들과는 달리 준 주 기적 격자구조를 가지며 경도 및 내부식성이 높고, 마 찰계수 및 계면에너지가 낮은 특성을 갖는다. ${ }^{7)}$ 따라서 제 2상으로 준 결정상을 갖는 합금은 기지와 석출상의 낮 은 계면에너지로 인하여 고온에서 석출상의 조대화가 억 제되기 때문에 분산강화 효과를 기대할 수 있다.

안정한 I-상의 존재는 Luo 등 ${ }^{8,9}$ 에 의해 처음으로 보고

${ }^{\dagger}$ Corresponding author

E-Mail : kapho@cnu.ac.kr (K. H. Lee)
되었으며, 그 구조는 cluster structure에 의해 두 종류로 분류된다. 하나는 Mackay-icosahedral cluster (MI-type)로 구성된 P-type으로 불리는 구조이며, 다른 하나는 rhombictriacontahedron cluster (FK- or RT-type)로 구성되며 F-type 구조로 부른다. 역공간에서MI-type은 단순 icosahedral 격 자를 가지며, FK-type은 면심 icosahedral 격자를 갖는다. ${ }^{10)}$ 주조용 $\mathrm{Mg}-\mathrm{Zn}-\mathrm{Y}$ 합금에서 I-상은 일반적으로 응고시 결 정입계에 조대한 공정상으로 형성되나, 고온 시효과정에 서도 나노 크기로 기지내에 석출하는 것으로 보고되어 있 다. ${ }^{11,12)}$ 공정 I-상은 열간 압연 또는 압출과 같은 가공 열처리에 의해 미세한 크기로 기지내에 분산 석출되며, 기지와 석출상의 낮은 계면에너지로 인하여 고온에서 I상들의 조대화는 억제된다. Singh 등 ${ }^{13-15)}$ 에 의하면 I-상 과 기지 사이에는 5 종류(OR1 - OR5)의 방위관계가 존재 하며, 2 종류의 방위관계는 쌍정에 의해 형성될 수 있음 을 보였다. 한편, $\mathrm{Kim}$ 등1)은 고온에서 열처리한 $\mathrm{Mg}_{96}$ $\mathrm{Zn}_{34} \mathrm{Y}_{0.6}$ 합금에서 기지와 특정한 방위관계를 갖지 않는 다 각형 형태의 I-상들이 석출하는 것을 관찰하였다.

본 연구에서는 $\mathrm{Mg}-6 \mathrm{wt} \% \mathrm{Zn}-1 \mathrm{wt} \% \mathrm{Y}$ 합금의 고온 시효과 정에서 석출한 I-상에 대하여 기지와의 방위관계 및 계 면구조를 고분해능 전자현미경을 이용하여 조사하였다. 특 히, 일부 I-상에서는 다중쌍정이 관찰되며 쌍정면은 I-상 
의 5 회 대칭축과 평행함이 확인되었다.

\section{2. 실험 방법}

본 연구에 사용된 $\mathrm{Mg}-6 \mathrm{wt} \% \mathrm{Zn}-1 \mathrm{wt} \% \mathrm{Y}$ 합금은 일본 히 다찌 메탈(주)에서 구입한 것으로 판재형태로 압연하였 다. 판재합금을 적당한 크기로 자른 후, 석영관에 진공봉 입하여 $550^{\circ} \mathrm{C}$ 에서 2 시간 동안 용체화처리를 한 다음 물 속에 급냉하였다. 용체화처리된 시편은 I-상의 석출거동을 조사하기 위하여 석영관속에 진공 봉입하여 $400^{\circ} \mathrm{C}$ 에서 10 시간 동안 시효처리를 하였다. 전자현미경 관찰용 시편은 연마포를 이용하여 약 $0.2 \mathrm{~mm}$ 의 두께로 연마 후 dimpling 에 의해 $80 \mu \mathrm{m}$ 의 두께까지 기계적 연마를 하였다. Dimpling 된 시편은 저온 챔버에서 $4.5 \mathrm{Kv}, 15^{\circ}$ 의 조건으로 ion milling에 의해 제작하였다. 전자현미경은 JEM 2010을 이용하여 고분해능상을 관찰하였으며, 석출상과 기지와의 방위관계 및 계면구조는 FFT (Fast Fourier Transform) 및 noise filtering을 이용하여 해석하였다.

\section{3. 결과 및 고찰}

Fig. 1 은 $550^{\circ} \mathrm{C}$ 에서 2 시간 동안 용체화처리한 시편에 서 얻은 명시야상으로, 결정입계에는 응고시 형성된 줄 무늬 형태의 조대한 공정 I-상들이 관찰된다. 공정 I-상 은 용체화처리 온도에서 안정하며 $\beta_{1}{ }^{\prime}, \beta_{2}$ '등과 같은 준 안정상들의 석출은 관찰되지 않는다.

$\mathrm{I}$-상은 5 회 회전대칭을 갖는 준 주기적 상으로, 역공간 에서 격자점들의 위치는 주기적이 아니라 황금비(Golden mean; $\tau=(1+\sqrt{5}) / 2=1.618034 \ldots)$ 로 알려진 무리수에 의해 나타난다. ${ }^{16)}$ 역공간에서의 대칭은 20 개의 이등변삼각형의

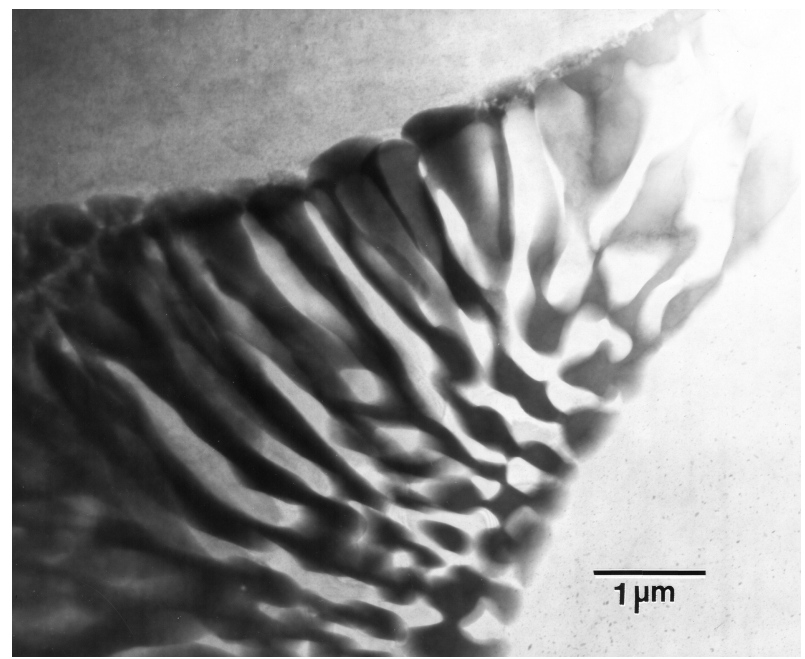

Fig. 1. TEM bright field micrograph showing eutectic I-phase in $\mathrm{Mg}-6 \mathrm{wt} \% \mathrm{Zn}-\mathrm{iwt} \% \mathrm{Y}$ alloy after solution treatment at $550^{\circ} \mathrm{C}$.
면을 갖는 정 20 면체와 동일하며, 12 개의 정점은 5 회 회 전대칭을 갖는다. I-상은 6 개의 5 회 정대축, 10 개의 3 회 정대축, 15 개의 2 회 정대축을 갖는다. I-상의 전자회절도 형에 나타난 회절점들은 준 주기적 특성 때문에 주기성 을 갖는 결정과 같은 방법으로 지수를 붙일 수 없다. I상의 지수를 붙이는 방법은 $\mathrm{Elser}^{17}$ 과 Cahn 등 ${ }^{18)}$ 에 의해 제안된 2종류의 방법이 사용되고 있으며, 모두 6자리의 정 수를 사용한다. 본 논문에서는 Elser에 의해 제안된 방법 을 사용하였으며, 5 회 역격자 벡터방향를 따라서 가장 가 까운 회절점의 지수는 $\{100000\}$ 이며, 5 회 및 2 회 역격자

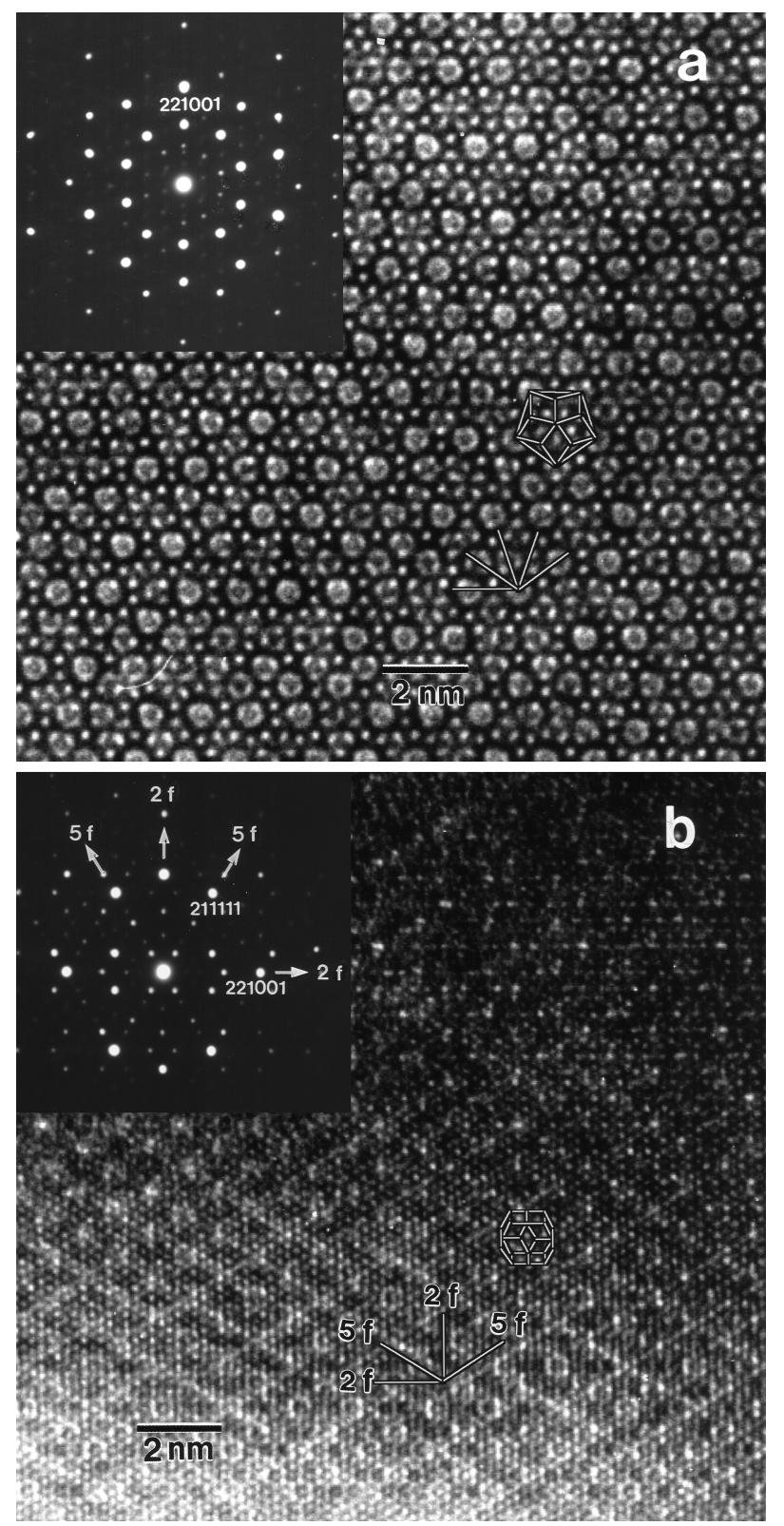

Fig. 2. HRTEM images of eutectic I-phase observed in Fig. 1, taken with the incident beam parallel to the five-fold zone axis (a) and twofold zone axis (b). Rhombic triacontahedron projected along the respective orientation directions are outlined in the HRTEM images. 
벡터방향를 따라서 가장 강한 회절점들의 지수는 각각 $\{211111\}$ 및 $\{221001\}$ 이다.

Fig. 2는 Fig. 1에서 관찰된 조대한 공정 I-상 영역의 고분해능상과 대응되는 전자회절도형이다. (a)는 5-회 정 대축 입사에 의한 고분해능상과 회절도형으로, 회절도형 에는 F-type 구조를 갖는 I-상에 의한 특징적인 규칙반 사들이 관찰된다. 고분해능상에는 단범위 주기를 갖는 밝 은 점(또는 검은 점)들이 관찰되며, 중앙에 약한 흰 점을 갖는 밝은 링과 이것을 둘러 싼 10 개의 밝은 점들을 갖 는 특징적인 구조단위를 볼 수 있다. 검은 영역이 원자 위치에 대응하는 높은 포텐샬을 갖는 영역이며, 밝은 곳 이 원자들 사이의 빈자리에 대응하는 낮은 포텐샬을 갖 는 영역에 대응된다. ${ }^{19)}$ 밝은 링과 10 개의 밝은 점의 구 조단위를 갖는 특징은 $\mathrm{AlMnSi}$ 및 $\mathrm{AlLiCu}$ 합금 ${ }^{19)}$ 에서 관 찰된 것과 매우 유사하며, 실선으로 표시한 바와 같이 능 형 30면체(rhombic triacontahedron) 원자 cluster를 5 회 대칭축에서 투영한 원자배열로부터 이해할 수 있다. (b) 는 2-회정대축 입사에 의한 고분해능과 전자회절도형으 로, 전자회절도형에는 $63.4^{\circ}$ 의 각을 갖는 2 개의 5 회 대 칭축 방향 $(5 \mathrm{f})$ 과 입사축과 $90^{\circ}$ 의 관계를 갖는 다른 2 개 의 2 회 대칭축 방향 $(2 \mathrm{f})$ 이 나타나 있다. 고분해능상에는 2 회 및 5 회 대칭축 방향을 따라서 배열된 밝은 점들이 관찰되며, 2 회 대칭축에서 투영된 능형 30 면체를 실선으 로 표시하였다.

Fig. 3 은 용체화처리후 $400^{\circ} \mathrm{C}$ 에서 10 시간 동안 시효처 리한 시편의 명시야상으로, 응고시 형성된 공정 I-상과 함 께 수백 $\mathrm{nm}$ 의 크기를 갖는 다각형 형태의 석출상들이 관찰된다. $\mathrm{Mg}-\mathrm{Zn}-\mathrm{Y}$ 합금에서 $\mathrm{I}-$ 상의 평형은 2 회 및 5 회 대칭면과 같은 낮은 에너지 면들에 의해 지배되며 오각

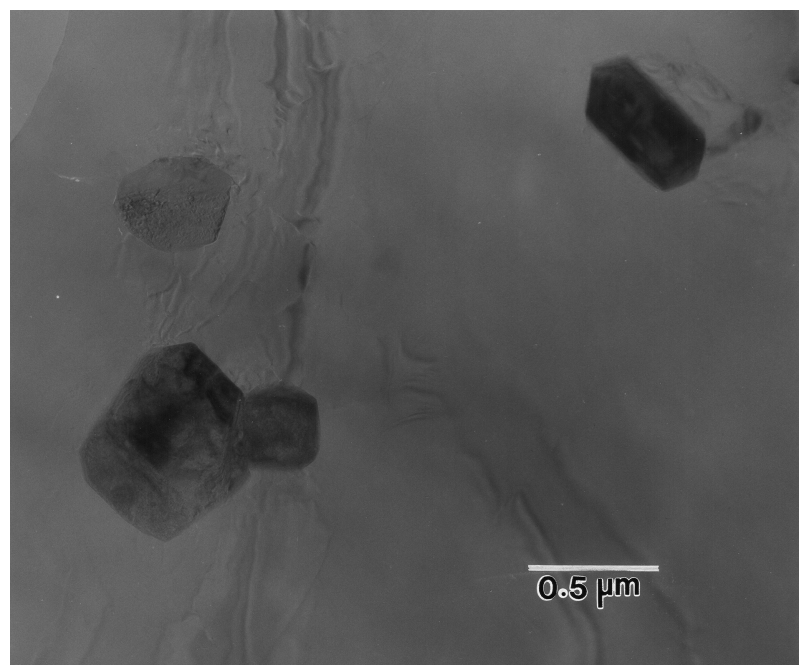

Fig. 3. TEM bright field micrograph showing polygon-shaped Iprecipitates in Mg- $6 \mathrm{wt} \% \mathrm{Zn}$-iwt $\% \mathrm{Y}$ alloy after annealing at $400^{\circ} \mathrm{C}$ for $10 \mathrm{hr}$.
형으로 된 12 면체의 형상으로 알려져 있다. ${ }^{20)}$ 기지와 I상의 접면은 기지의 기저면들과 I-상의 2 회 및 5 회 대 칭면, 또는 기지의 $\{100\}$ 면들과 I-상의 2 회 및 5 회 대 칭면들의 접촉에 의해 우선적으로 형성된다. ${ }^{14)}$

Fig. 4 는 $400^{\circ} \mathrm{C}$ 에서 열처리한 시편에서 관찰된 $\mathrm{I}$-상의 5 회 정대축 입사에 의한 고분해능상(a)과 전자회절도형(b) 으로, 고분해능상의 기지영역에는 세 방향으로 $\{100\}$ 면 간거리에 대응하는 격자줄무늬들이 나타나 있으며, IQC 로 표시한 영역에는 인접하여 석출한 수백 $\mathrm{nm}$ 크기의 $\mathrm{I}$-상 $\mathrm{A}, \mathrm{B}$ 가 관찰된다. 각 $\mathrm{I}$-상 내에 $36^{\circ}$ 의 각을 갖고 표시된 흰 선들은 I-상의 5 회 정대축 입사에 의한 2 회 대
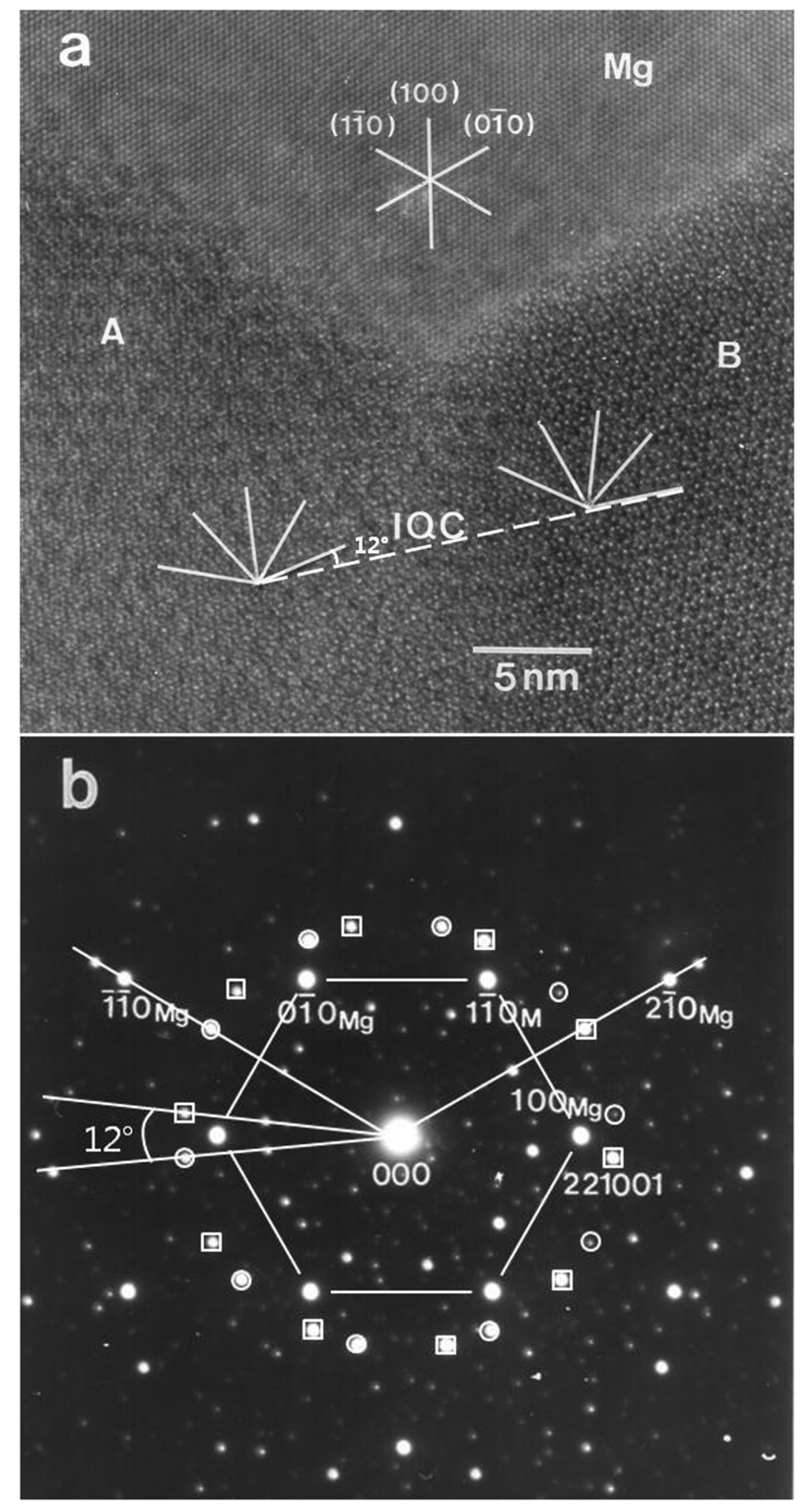

Fig. 4. HRTEM image (a) and the corresponding selected-area diffraction pattern (b) of the I-phase precipitate taken with the incident beam parallel to the five-fold zone axis. The matrix reflections are marked by a hexagon. in (b). 
칭면들을 나타낸 것으로, $\mathrm{A}$ 와 $\mathrm{B}$ 는 5 회 정대축을 중심 으로 $12^{\circ}$ 회전되어 있음을 볼 수 있다. 대응되는 전자 회절도형에는 실선으로 표시한 바와 같이 기지의 [001] 입사에 의한 기본격자반사들과 F-type 구조를 갖는 I-상 의 5 회 정대축 입사에 의한 많은 회절점들이 관찰된다. I상에 의한 회절점들 중에서 2회 대칭축 방향의 \{221001\} 회절점들은 원과 사각형으로 표시한 바와 같이 2 쌍이 관 찰된다. 원으로 표시한 것은 고분해능상(a)에 $\mathrm{A}$ 로 표시한 $\mathrm{I}$-상에 의한 회절점들이며, 사각형으로 표시한 것은 $\mathrm{B}$ 로 표 시한 I-상에 의한 회절점들에 대응된다. 이들 두 회절점들 은 단지 입사빔 축(5회 정대축)을 중심으로 $12^{\circ}$ 회전되어 있음을 알 수 있다. A로 표시한 I-상에 의한 5 개의 2 회 대 칭축 방향 중 하나는 기지의 [210] 방향과 일치하며, B상 에 의한 2 회 대칭축 방향도 5 개 중 하나는 기지의 [ $\overline{1} \overline{1} 0]$ 방향과 일치함을 볼 수 있다. 기지의 [2 $\overline{1} 0]$ 과 $[\overline{1} \overline{1} 0]$ 는 등가 방향으로 $\mathrm{I}-$ 상 $\mathrm{A}$ 와 $\mathrm{B}$ 는 기지와 동일한 방위관계를 갖고 있음을 알 수 있다. 즉, $\mathrm{I}-$ 상 $\mathrm{A}, \mathrm{B}$ 는 모두 기지와 $[\mathrm{I}]_{\mathrm{I}} / /[001]_{\mathrm{Mg}},(2 \mathrm{f})_{\mathrm{I}} / /\{\overline{1} \overline{1} 0\}_{\mathrm{Mg}}$ 의 방위관계를 만족한다.

Fig. 5는 Fig. 4에서 관찰된 기지와 I-상의 방위관계와 는 다른 방위관계를 갖고 석출한 I-상의 명시야상(a)과 회 절도형(b)이다. 회절도형에는 I-상의 2 회 정대축과 기지의 [311] 입사에 의한 회절점들이 관찰된다. I-상의 2회 정 대축 입사에 의한 반사에는 서로 $90^{\circ}$ 의 관계를 갖는 2 회 대칭축 방향 $(2 \mathrm{f})$ 과 육방정계의 $60^{\circ}$ 에 가까운 $63.4^{\circ}$ 의 관 계를 갖는 5 회 대칭축 방향 $(5 \mathrm{f})$ 이 나타나 있다. 사선으로 연결한 직사각형은 I-상의 5회 대칭축 방향의 (211111) 반 사점들을 연결한 것으로, 가로와 세로의 비가 황금비 $\tau$ 를 갖는 사각형이다. 한편 기지에 의한 회절점들은 $0 \overline{1} 1$, $\overline{1} 12$ 및 이들의 등가위치에서 관찰되며, 입사빔은 [311] 정대축과 거의 평행함을 알 수 있다. 육방정계의 [311] 정 대축 입사에 의한 [0 $\overline{1} 1]$ 방향과 [ $\overline{1} 12]$ 방향의 사잇각 은 $90^{\circ}$ 가 아닌 $88.56^{\circ}$ 를 갖는다. I-상의 5 회 대칭축 방향 의 211111 반사위치는 기지의 $0 \overline{1} 1$ 반사위치와 일치하 는 것을 볼 수 있다. 이것은 $\mathrm{Mg}-\mathrm{Zn}$-Y계에 존재하는 I상의 준 격자상수(quasilattice parameter)는 $0.52 \mathrm{~nm}$ 이므 로, ${ }^{20)} 2$ 회 대칭축 방향의 $\{211111\}$ 면간거리는 $0.243 \mathrm{~nm}$ 가 된다. 따라서 기지의 $(0 \overline{1} 1)$ 면간거리 $0.245 \mathrm{~nm}$ 와는 약 $0.8 \%$ 의 아주 작은 차이를 갖기 때문이다. 회절도형으로 부터 I-상과 기지와의 방위관계는 [I2 $]_{\mathrm{I}} / /[311]_{\mathrm{Mg}},(5 \mathrm{f})_{\mathrm{I}} / /$ $(0 \overline{1} 1)_{\mathrm{Mg}}$ 임을 알 수 있다.

명시야상(a)에는 기지에 석출한 $300 \mathrm{~nm}$ 크기의 다각형 의 I-상이 관찰되며, 기지와 I-상의 계면은 I-상의 2 회 및 5 회 대칭면상에 놓이는 것을 알 수 있다. 특히, 5 회 대 칭면상의 계면보다 2회 대칭면상의 계면이 보다 넓은 특 징을 보인다. 이것은 20 면체가 회절도형(b)에 나타난 바 와 같이 서로 수직한 3 개의 2 회 정대면들을 갖게 되기
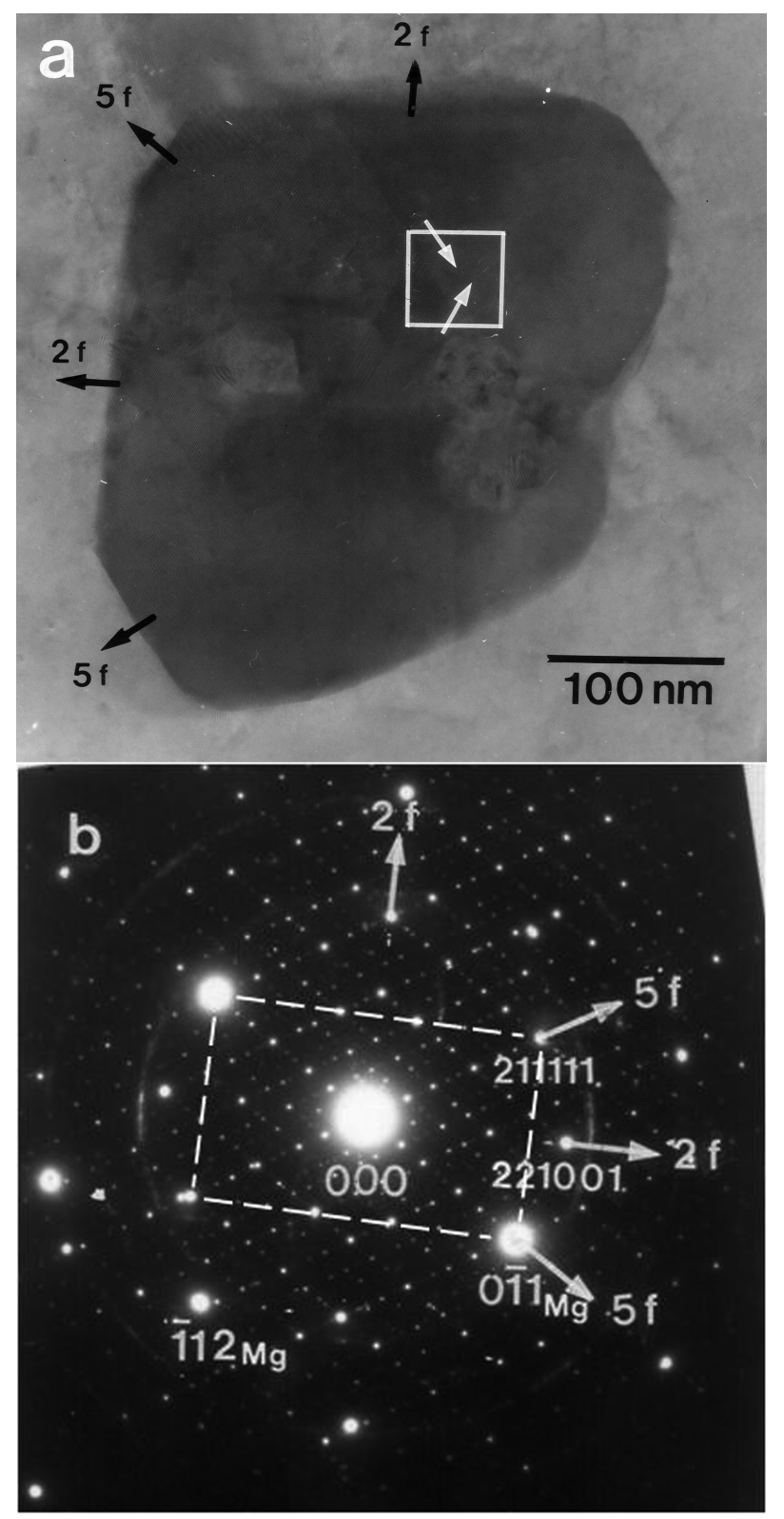

Fig. 5. TEM bright field micrograph (a) and the corresponding selected-area diffraction pattern (b) of the I phase precipitate taken with the incident beam parallel to the two-fold zone axis. The interfaces between the I-phase and the matrix are on five-fold and two-fold planes of the icosahedral phase.

때문에 육방정계를 갖는 기지에서 서로 수직한 낮은 에 너지 면들의 연결을 돕기 때문이다. ${ }^{14)}$ 특히, I-석출상 내 부에는 화살표로 표시한 바와 같이 특정한 방향을 따라 서 선상의 결함 컨트라스트들이 관찰된다.

Fig. 6은 Fig. 5에서 흰 선으로 표시한 사각형 영역의 고분해능상(a)과 대응되는 FFT도형(b)이다. I상의 2회 정 대축 입사에 의한 고분해능상에는 $\mathrm{A}, \mathrm{B}, \mathrm{C}$ 로 표시한 바 와 같이 서로 다른 방위관계를 갖는 영역들이 관찰된다. 각 영역에서 5 회 대칭면들을 $5 \mathrm{f}_{\mathrm{A}}, 5 \mathrm{f}_{\mathrm{B}}$ 및 $5 \mathrm{f}_{\mathrm{C}}$ 로 각각 표 


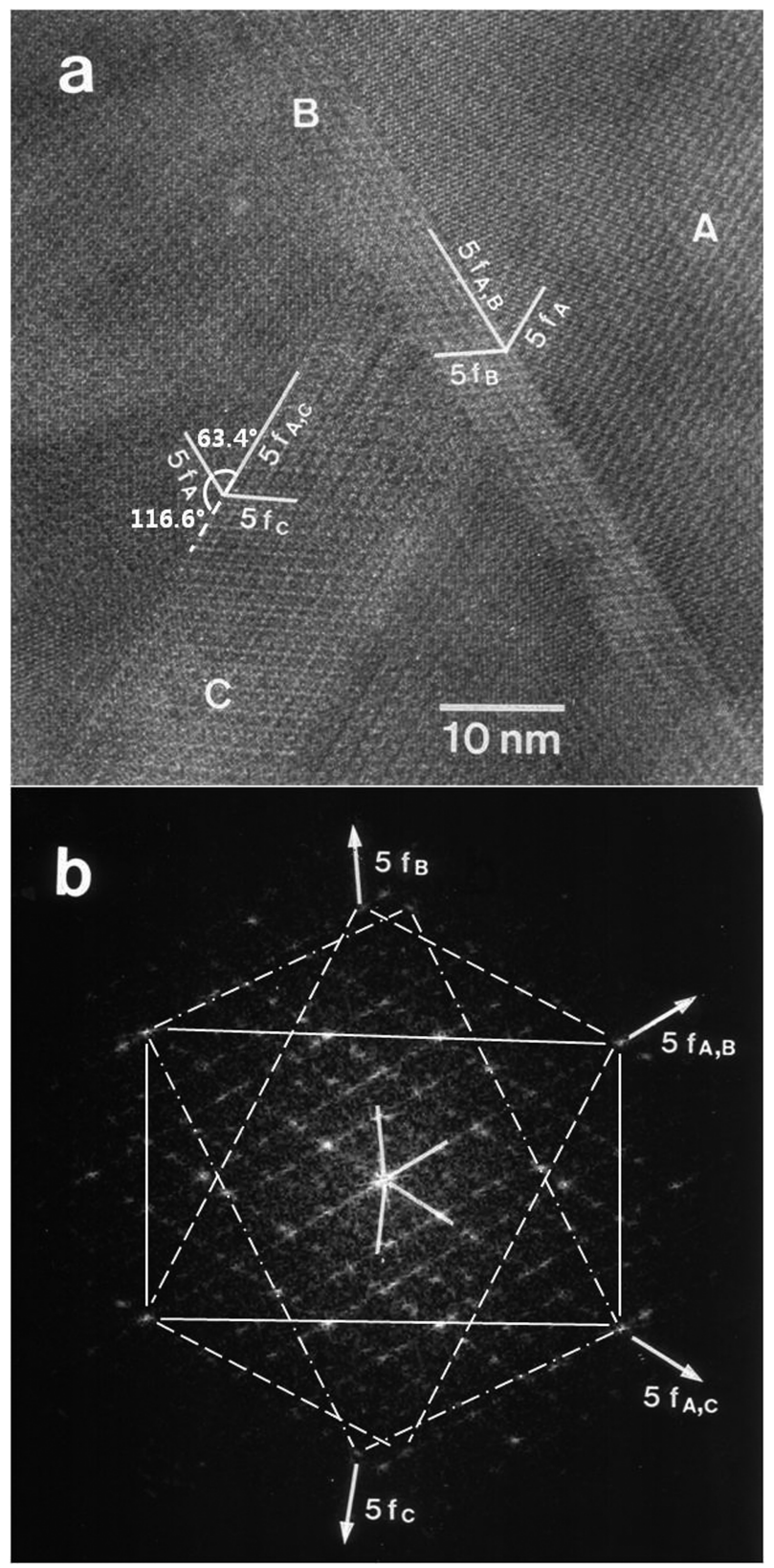

Fig. 6. HRTEM image (a) and the corresponding FFT pattern (b) of the marked area in Fig. 5. The regions $\mathrm{A}$ and $\mathrm{B}$ and $\mathrm{A}$ and $\mathrm{C}$ are twin related with a common five-fold axis as the twin axis, respectively.

시하였으며, 영역 $\mathrm{A}$ 와 $\mathrm{B}$ 및 $\mathrm{A}$ 와 $\mathrm{C}$ 는 각각 서로 다른 5 회 대칭면을 공유하고 있음을 볼 수 있다. 대응되는 FFT 도형에는 고분해능상(a)에 표시한 $\mathrm{A}, \mathrm{B}, \mathrm{C}$ 세 영역에 의한 복잡한 회절점들이 관찰된다. 실선과 점선 및 사선으로 표 시한 직사각형은 각각 영역 $\mathrm{A}, \mathrm{B}, \mathrm{C}$ 에 의한 회절점들 중 에서 황금비를 갖는 사각형(golden rectangle)을 표시한 것 이다. $5 \mathrm{f}_{\mathrm{A}}, 5 \mathrm{f}_{\mathrm{B}}$ 및 $5 \mathrm{f}_{\mathrm{C}}$ 는 각각 $\mathrm{A}, \mathrm{B}$ 및 $\mathrm{C}$ 영역에 의한 5 회 대칭축 방향을 나타낸 것으로, 영역 $\mathrm{A}$ 와 $\mathrm{B}$ 및 $\mathrm{A}$ 와 $\mathrm{C}$ 는 각각 쌍정관계를 가지며, 쌍정면은 모두 5 회 대칭면
임을 알 수 있다. 이와 같은 쌍정은 2회 대칭축 방향을 중심으로 $63.4^{\circ}$ 또는 $116.6^{\circ}$ 의 회전에 의해 형성된다. 다 중쌍정을 갖는 I-상의 형성에 의해 기지와 I-상 사이에는 보다 복잡한 방위관계가 예상된다.

\section{4. 결 론}

$\mathrm{Mg}-6 \mathrm{wt} \% \mathrm{Zn}-1 \mathrm{wt} \% \mathrm{Y}$ 합금에서 석출하는 준결정I-상의 방 위관계 및 계면구조를 전자현미경을 이용하여 관찰한 결 과는 다음과 같다.

1. I-상은 응고시에 조대한 공정조직으로 우선 정출되 며, $400^{\circ} \mathrm{C}$ 에서 시효처리에 의해 수백 $\mathrm{nm}$ 크기의 F-type 구조를 갖는 다각형의 $\mathrm{I}-$ 상이 석출된다.

2. 기지내에 석출한 $\mathrm{I}-$ 상은 기지와 $[\mathrm{I}]_{\mathrm{I}} / /[001]_{\mathrm{Mg}},(2 \mathrm{f})_{\mathrm{I}}$ $(2 \overline{1} 0)_{\mathrm{Mg}}$ 와 [I2] $]_{\mathrm{I}} / /[311]_{\mathrm{Mg}},(5 \mathrm{f})_{\mathrm{I}} / /(0 \overline{1} 1)_{\mathrm{Mg}}$ 방위관계를 만 족한다.

3. 기지와 $\mathrm{I}-$ 상의 계면은 $\mathrm{I}-$ 상의 2 회 및 5 회 대칭면상 에 놓이며, 2 회 대칭면상의 계면은 5 회 대칭면상의 계 면보다 넓다.

4. 일부 석출 $\mathrm{I}$-상 내부에는 5 회 대칭축을 쌍정축으로 하는 다중쌍정이 관찰되며, 2회 대칭축을 중심으로 $63.4^{\circ}$ 또는 $116.6^{\circ}$ 의 회전에 의해 형성된다.

\section{참 고 문 헌}

1. M. X. Zang and P. M. Kelly, Scripta Mater., 48, 379 (2003).

2. J. F. Nie, Scripta Mater., 48, 1009 (2003).

3. Z. P. Luo, S. Q. Zhang, Y. L. Tang and D. S. Zhao, Scripta Metall. Mater., 32, 1411 (1995).

4. D. H. Bae, S. H. Kim, D. H. Kim and W. T. Kim, Acta Mater., 50, 2343 (2002).

5. A. Singh, M. Nakamura, M. Watanabe, A. Kato and A. P. Tsai, Scripta Mater., 49, 417 (2003).

6. W. J. Kim, S. I. Hong and K. H. Lee, Metals and Materials Int., 16, 171 (2010).

7. F. S. Pierce, S. J. Poon and Q. Guo, Seience, 261, 737 (1993).

8. Z. Luo, S. Zhang, Y. Tang and D. Zhao, Scripta Metall. Mater., 28, 1513 (1993).

9. Z. P. Luo, S. Q. Zhang, Y. L. Tang and D. S. Zhao, Scripta Metall. Mater., 32, 1411 (1995).

10. S. Ebalard and F. Spaepen, J. Mater. Res., 4, 39 (1989).

11. I. J. Kim, D. H. Bae and D. H. Kim, Mater. Sci. Eng., A359, 313 (2003).

12. S. Y. Baek, K. H. Lee and T. S. Kim, Kor. J. Mater. Res., 18(7), 362 (2008) (in Korean).

13. A. Singh, A. P. Tsai, M. Nakamura, M. Watanabe and A. Kato, Phil. Mag. Lett., 83(9), 543 (2003).

14. A. Singh, M. Watanabe, A. Kato and A. P. Tsai, Mater. 
Sci. Eng., A397, 22 (2005).

15. A. Singh, M. Watanabe, A. Kato and A. P. Tsai, Acta Mater., 53, 4733 (2005).

16. D. Shechtman, I. Blech, D. Garatias, J. W. Cahn, Phys. Rev. Lett., 53, 1951 (1984).

17. V. Elser, Phys. Rev., B32, 4892 (1985).
18. J. W. Cahn, D. Shechtman and D. Gratias, J. Mater. Res., 1, 13 (1986).

19. K. Hiraga, J. Electron Microsc., 40, 81 (1991).

20. A. Niikura, A. P. Tsai, A. Inoue and T. masumoto, Phil. Mag. Lett., 69(6), 351 (1994). 